\title{
PENGARUH KUALITAS UDARA BILAS TERHADAP PROSES PEMBAKARAN PADA MESIN TYPE MATSHUI 31 M-29 \\ Santhi Wilastari ${ }^{1)}$, Djajari ${ }^{2)}$ \\ ${ }^{1), 2)}$ Program Studi Teknika Akademi Pelayaran Niaga Indonesia santhi@akpelni.ac.id
}

\begin{abstract}
ABSTRAK
Dengan berkembangnya dunia ilmu pengetahuan dan teknologi, khususnya dan segi transportasi laut, sangatlah efisien untuk memenuhi sarana angkutan dari satu negara ke negara lain. Dalam hal ini kapal laut mempunyai peranan yang sangat penting untuk memenuhi kebutuhan tersebut. Sesuai dengan ketentuan dunia ilmu pengetahuan dan teknologi, dalam pengoperasian kapal diperlukan tenaga-tenaga yang professional. Begitu juga dalam perawatan alat-alat yang ada di atas kapal dan yang menunjang kelancaran gerak kapal. Salah satunya adalah perawatan terhadap motor diesel kapal. Dalam peranan dan fungsinya, motor diesel pada kapal merupakan bagian yang sangat penting dalam menunjang proses kelancaran dalam pelayaran dan kapal itu sendiri. Untuk menjaga agar motor diesel kapal tetap baik dan dapat memberikan manfaat yang maksimal perlu adanya perawatan. Salah satunya dengan diadakan pembilasan. Dimana pembilasan ini berguna untuk mengeluarkan gas-gas bekas dan silinder dan menggantinya lagi denganbahan bakar (udara) baru. Dengan demikian silinder tetap bersih sehingga dapat menunjang kelancaran gerak kapal itu sendiri. Sehubungan dengan hal tersebut di atas, maka timbul keinginan penulis untuk mengetahui lebih banyak tentang pembilasan.
\end{abstract}

Kata kunci : udara bilas, pembakaran, motor diesel 


\section{Latar Belakang Masalah}

Dengan berkembangnya dunia ilmu pengetahuan dan teknologi, sangatlah mutlak diperlukan tenaga-tenaga yang terampil dan professional guna memenuhi kebutuhan untuk menciptakan peralatan yang canggih dan modern sesuai dengan perkembangan dunia ilmu pengetahuan dan teknologi. Khususnya dan segi transportasi laut, sangatlah efisien untuk memenuhi sarana angkutan dari satu negara ke negara lain. Dalam hal ini kapal laut mempunyai peranan yang sangat penting untuk memenuhi kebutuhan tersebut.

Sesuai dengan ketentuan dunia ilmu pengetahuan dan teknologi, dalam pengoperasian kapal diperlukan tenagatenaga yang professional. Begitu juga dalam perawatan alatalat yang ada di atas kapal dan yang menunjang kelancaran gerak kapal. Salah satunya adalah perawatan terhadap motor diesel kapal.

Dalam peranan dan fungsinya, motor diesel pada kapal merupakan bagian yang sangat penting dalam menunjang proses kelancaran dalam pelayaran dan kapal itu sendiri. Untuk menjagaagar motor diesel kapal tetap baik dan dapat memberikan manfaat yang maksimal perlu adanya perawatan. Salah satunya dengan diadakan pembilasan. Dimana pembilasan ini berguna untuk mengeluarkan gas-gas bekas dan silinder dan menggantinya lagi denganbahan bakar (udara) baru. Dengan demikian silinder tetap bersih sehingga dapat menunjang kelancaran gerak kapal itu sendiri.

Sehubungan dengan hal tersebut di atas, maka timbul keinginan penulis untuk mengetahui lebih banyak tentang pembilasan. Dalam rangka mempelajari proses dan prosedur penggunaan dan fungsi-fungsi pembilasan lebih dari itu penulis ingin mengenal :

1. Bagaimana manfaat pembilasan serta proses pembilasan.

2. Pekerjaan-pekerjaan apa saja yang harus dilakukan oleh crew kapal. 
3. Dasar dan prinsip kerja pembilasan.

\section{PEMBAHASAN}

\section{Manfaat Proses Pembilasan}

Pembuangan gas-gas bekas dari silinder setiap kali sesudah pembakaran, dan menggantikannya lagi dengan udara pembakaran baru adalah salah satu bagian yang penting dan proses dua lak. Bagian yang penting ini disebut pembilasan silinder dan biasanya diselenggarakan selama $10 \%$ terakhir dari langkah usaha dan 10\% dan langkah kompresi. Waktu yang tersedia untuk pembilasan ini singkat sekali, hingga sukar mengusahakannya supaya pembilasan tersebut dapat dilakukan sebaik-baiknya.

Untuk mengeluarkan gas-gas bekas menjadi terlampau tinggi, hingga mengakibatkan gesekan atau hambatan besar yang berarti kerugian tenaga motor. Lagi pula akibat dari kecepatan yang besar dan gas-gas/udara baru yang masuk ke silinder, maka sebagian daripadanya akan bercampur dengan gas-gas bekas, hingga pengisian silinder tidak lagi dapat dikatakan bersih.

Pembuatan pintu-pintu pembilas pada dinding silinder adalah suatu perbaikan, walaupun dalam hal ini masih ada cacatnya. Pada motor-motor yang memakai berhubungan dengan ini maka kompresinya baru mulai sesudah $20 \%$ dari permulaan langkah, hingga pada akhir langkah dalam silinder terdapat gas/udara yang juga $20 \%$ kurangnya, jika dibandingkan dengan motor 4 tak dengan isi langkah yang sama. Hal ini disebabkan karena pada motor 4 tak tersedia satu langkah penuh untuk kompresinya. Seperti telah kita ketahui banyaknya bahan bakar yang dapat dibakar, sedangkan pembakaran ini akhirnya menentukan besar kecilnya tenaga motor yang dapat diberikan untuk tiap-tiap proses usaha.

Dengan demikian maka motor 2 tak memberikan tenaga $100 \%$ - $20 \%$ - $80 \%$ atau 0,8 sebesar tenaga motor 4 tak yang 
ukuran-ukurannya sama. Tetapi karena pada perputaran proses engkol yang sama jumlah proses usaha motor 2 tak dapat memberikan tenaga $2 \times 0,8=1,6$ sebesar motor 4 tak.

Untuk pembilasan yang sempurna dibutuhkan udara sebanyak 1,5 kali isi silinder. Hal ini tak cukup diperoleh dengan mempergunakan torak dan peti poros engkol saja, karena ternyata bahwa torak tidak dapat menghasilkan udara lebih dari isi silinder dikurangi dengan isi ruang bakar. Pembilasan dengan perantaraan peti poros engkol didapat pada beberapa motor (kecil) saja. Bukanlah karena taraf kebaikan pembilasannya, tetapi karena pembilasan semacam ini menyebabkan bentuk motor menjadi sangat sederhana.

Kita telah meyakini pula bahwa pembilasan harus dapat diselesaikan dalam waktu sesingkat-singkatnya, dan sedapat mungkin diusahakan supaya kemungkinan gas-gas bekas bercampur dengan gas-gas/udara baru dapat dibatasi sekecilkecilnya. Di samping itu semua perlu diperhatikan pula hambatan-hambatan yang diberikan lubang-lubang laluan dari klep dan pintu-pintu pembilas memasukkan gas-gas/udara baru ke dalam silinder.

\section{Efek Pembilasan}

Harga efisiensi pembilasan versus perbandingan pembilasan tidak diperbolehkan dari pengukuran pada mesin sebenarnya, tetapi dari pengukuran terhadap aliran udara stasioner melalui model silinder. Dalam keadaan sebenarnya aliran udaratersebut tidak stasioner dan di samping itu torak bergerak bolak-balik. Namun, pengalaman menunjukkan bahwa sistem- sistem yang memberikan hasil baik dalam pengujian dengan stasioner, dapat menghasilkan daya yang besar dalam keadaan sebenarnya yang bekerja dengan aliran tak stasioner. Boleh dikatakan bahwa pembilasan menunjukkan efisiensi pembilasan terendah dan pembilasan searah memberikan efisiensi tinggi, sedangkan untuk sistem yang sama perbedaan yang terjadi tergantung 
pada konstruksi lubang pembilasannya.

Dengan demikian pembilasan memanjang banyak memberikan keuntungan dibanding dengan pembilasan melintang dan pembilasan membalik. Keuntungan tersebut antara lain :

1. Efek pembilasan lebih besar dibandingkan dengan pembilasan silinder. Efek pembilasan besar tersebut dicapai dengan ratio pembilasan yang lebih kecil.

2. Efek pembilasan yang baik dapat dicapai pada langkah relatif panjang dan torak.

3. Lapisan silinder dibeban termis tidak terlalu besar secara termis dibandingkan dengan pembuangan gas melalui pintu dalam dinding silinder, karena aliran gas buang terjadi melalui tutup silinder.

Hal ini sangat penting untuk menjaga lapisan pelumas pada dinding silinder dan juga untuk keausan dari pegas torak dan lapisan silinder.

Jika dibandingkan dengan pembilasan melintang, efisiensi pembilasan dengan difusi sempurna lebih baik. Hal ini disebabkan karena pada pembilasan melintang udara segar dapat langsung keluar dari dalam silinder.

Ada suatu cara untuk mengambil sampel gas dari dalam silinder, pada waktu proses kompresi dan proses ekspansi, kemudian memeriksa komposisinya. Karena katup elektromagnetis yang memungkinkan pengambilan sampel tersebut dapat dilakukan dengan jalan membuat lubang sampel pada dinding silinder.

\section{Perawatan Pompa Bilas}

Yang perlu diperhatikan dalam perawatan pompa bilas, kita harus mengetahui dulu cara kerja dan jenisnya. Bila menggunakan sistem torak, maka perawatan perlu dilakukan pada sistem pelumasannya, untuk bagian-bagian yang 
bergerak seperti torak, poros engkol, sistem pendingin dan juga kerja klep isap dan tekan. Karena besar kecilnya udara yang masuk ditentukan dari kerja torak yang bagus, dan putaran poros engkolnya. Bila pelumasannya kurang baik maka akan mengurangi kerja dari pompa bilas itu sendiri. Dan pada kerja klep-klepnya, yaitu klep isap dan tekan. Jadi bila klep isap bekerja tidak normal karena tersumbat akibat kotor maka jumlah udara yang masukpun kurang dari apa yang dibutuhkan. Begitu pula pada klep tekan, udara yang akan ditekan ke silinder yang akan dibilas akan kecil.

Bila menggunakan sistem kipas/blower yang perlu diperhatikan adalah kebersihan rumah pompa. Mengingat sudu-sudu jalan merupakan jalan udara masuk pada saat pengisapan, maka perlu dijaga jangan sampai sudusudu jalan rusak. Electromotor pada pompa, juga klep pengaturan.

Pompa-pompa bilas ini digerakkan oleh motor induk melalui rantai dan roda-roda gigi. Untuk itu pelumasan rantai dan roda gigi perlu dilakukan. Sehingga tidak terjadi keausan pada roda-roda gigi dan rantai tersebut.

\section{Kesimpulan}

Berdasarkan hasil dari pembahasan pada bab sebelumya, maka penulis dapat mengambil beberapa kesimpulan yang berhubungan dengan masalah yang menjadi penyebab terjadinya kerusakan dan cara mengatasinya sebagai penunjang pengoprasian kapal. Adapun kesimpulan yang dapat penulis ambil yaitu :

1. Penyebab tekanan udara bilas yang masuk ke ruang bakar karena kurang maksimal

a. Keruskan pada turbo charger

b. Kelainan kerja pada inter cooler c. Kerusakan pada klep

2. Penyebab penurunan daya mesin 
a. Udara kompresi kurang maksimal

b. Sistem bahan bakar kurang maksimal

c. Timbulnya percikan api pada pembilasan mesin induk

\section{DAFTAR PUSTAKA}

Aslang. 2000. Motor Diesel dan Turbin Gas I. Makassar : Politeknik Ilmu Pelayaran Makassar.

Boentarto. 1997.Teknik Motor Diesel Mobil.

Gottrfied Nist.1994. Marine Auxiliary Machinery. 6 edition. Butterworths: Harsanto.

1997.Motor Bakar. Djambatan

LA. De Bruijn dan L. Mulwijk. 1994.Motor Bakar. Jakarta : BhataraLondon. Solo : Aneka.

P. Van Maanen. Motor Diesel Kapal Jilid 2. Nautech

Thomas Krist. 1990. Marine Diesel Engine. Engine Series Newnes: Butterwoetth.

Wiranto Aris Munandar, Koichi Tsuda. 1983.Motor Diesel Putaran Tinggi. Jakarta : Pradnya Paramita. 